\title{
A review and further analysis on seafood processing and the development of the fish Pangasius from the food industry perspective
}

\author{
Dinh Tran Ngoc HUY ${ }^{1}$, Vu Quynh NAM², Hoang Thanh HANH ${ }^{3 *}$ (i), Pham Ngoc MINH${ }^{4}$, Le Thi Thanh HUONG 5
}

\begin{abstract}
Vietnam's seafood processing industry, in the specific, and the agricultural industry, in general, has gained many benefits and achievements to contribute to the GDP growth of Vietnam in recent years. Using qualitative analysis, synthesis, and inductive methods, with statistic data, this study examines the theories of inter-industry clusters or groups views applied in the agriculture and seafood processing industry, esp in a case study of the Tra fish (Pangasius hypophthalmus) in Mekong Delta River in Vietnam. Our results relate to seafood processing in the case study of fish pangasius in the Mekong delta in Vietnam. For instance, the present study shows that making seafood from tra fish (or pangasius describes processing fillet Tra fish (Pangasius hypophthalmus) in a 3-step process. Last but not least, through our analysis, analysis had suggested suitable agricultural policies. In conclusion, the empirical results have shown that making fillet Tra fish needs to have enough experience and skills under certain conditions. Besides, our study also indicated that increasing the application of new technologies in the rearing stage of fish such as: using probiotics, vaccines, and rearing in cool houses to increase the resistance of fingerlings to improve survival rate and efficiency for production. Finally, the empirical results have shown that the process of making fillet tra fish (pangasius) needs to have enough experience, skills and take place under certain conditions.
\end{abstract}

Keywords: seafood processing; pangasius; tra fish; agricultural development; food industry.

Practical Application: Present review shows new practical solutions for seafood processing for special kind of fish in Asiatic region.

\section{Introduction}

The theory of industrial clusters has been widely applied in industrialized countries, emerging industrial countries as well as many developing countries (Baldassarre et al., 2019; Chakrabarty, 2020; Choi \& Jiang, 2021; Han et al., 2018; Turkina \& Van Assche, 2018; Wu, 2018). However, the industrial cluster is still quite new in Vietnam, often translated and understood with many different names such as industrial cluster, industrial cluster, or industry cluster (Pham \& Nguyen, 2012). Industrial clusters (hereafter clusters) play an important role in economic development. Certain aspects of geography can fall within the discipline of economics for two main reasons (Malmberg et al., 1996). First, it is the nature of human beings to be clustered in certain places, leading to national and regional specialization. Hence it can try to apply cluster theory in the seafood processing industry of Vietnam, esp. In Vietnam, the quantity of exporting the Tra fish overseas has been increasing; looking at the below chart, we can see the exporting number increased highest in the year 2018 (see Figure 1).

On the other hand, Tra fish (fish pangasius) industry in the Mekong delta over the years also face challenges such as issues of concern, in which the low export price, the imbalance between the large export processing enterprises, the lack of healthy competition, poor promotion, and not finding many other potential markets have caused the fish pangasius always at a disadvantage (Neubacher, 2010; Nguyen \& Jolly, 2018).

The synchronous value chain from production, processing, and consumption of products with the participation of enterprises and farmers is not tight; the seed is an important step, but it does not meet the requirements; the market organization has many loopholes; have not fully exploited the potential and advantages of the large export market (Lee \& Whang, 2004; Misganaw, 2020).

Therefore, the pangasius industry suffers very heavy losses (Kaewnuratchadasorn et al., 2020). The most obvious example of damage to the industry has just occurred: the "double" impact of the drought and the Covid-19 pandemic in early 2020 . According to statistics, at the beginning of 2020 , the pangasius output reached nearly 180 thousand tons, down $23.6 \%$ over the same period in 2019 (Kaewnuratchadasorn et al., 2020).

${ }^{1}$ Banking University HCMC, Vietnam National University Ho Chi Minh City, International University of Japan, Niigata, Japan

${ }^{2}$ Thai Nguyen University of Economics and Business Administration - TUEBA, Hanoi, Vietnam

${ }^{3}$ Academy of Policy and Development - APD, Hanoi, Vietnam

${ }^{4}$ Office of National S\&T Program for Sustainable Development Mekong Delta Region, Vietnam National University Ho Chi Minh, Vietnam

${ }^{5}$ Dai Nam University, Hanoi, Vietnam

*Corresponding author: hoangthanhhanh@apd.edu.vn 


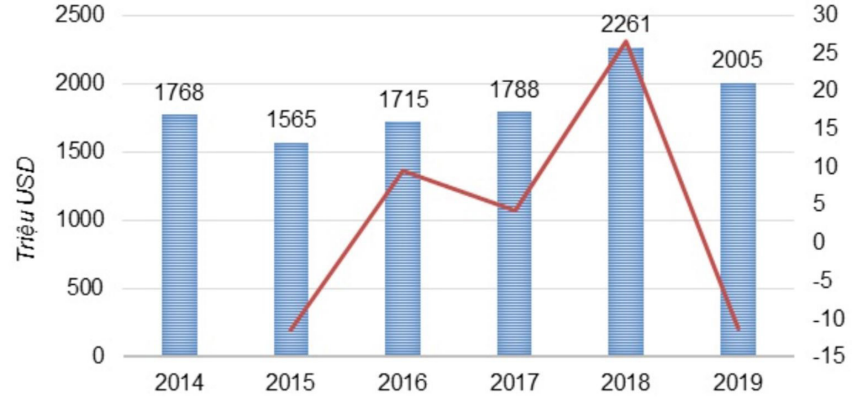

Figure 1. Exporting Tra fish of Vietnam 2015-2019.

\subsection{Research questions}

Question 1: What are previous studies and theories of inter-industry clusters, and what are the issues of the Vietnam pangasius industry?

Question 2: What are finished products we can make from tra fish (pangasius) in Vietnam and pangasius processing description?

Question 3: What are solutions for the Development of the pangasius industry groups in the Mekong Delta as a case?

\subsection{Literature review}

First of all, Lindsay (2005) stated that knowledge about networks and clusters is enhanced with complexity theory and its component concepts, such as coevolution and self-organization, which give out meaningful insights. Bekele \& Jackson (2006) stated that there are many discussions in recent years on industry clustering theories and concepts of regional economic development theory and practice. They found out that failures in finding accepted theoretical framework based on the discussion.

In addition, Motoyama (2008) found that Michael Porter's cluster theory, although popular in academic and policy, also received many critiques. For instance, it showed two limitations: descriptive theory has limited ability to replicate a successful cluster in practice. And moreover, it is hard to measure the interconnectedness of a cluster; it failed to explain how exactly the public sector can enhance this side.

So Huy (2016) has stated that groups of companies in the economy can be classified into groups (called clusters), for example, seafood-agriculture-export-commerce, constructionreal estate-material, banking-finance-stock investment-insurance, electric-water-gas -utilities, etc. Then we can estimate market risks and proposed certain public policies.

\subsection{Acceptability of tra fish (Pangasius hypophthalmus)}

Regarding present aqua food quality and acceptability, Tuan \& Dzung (2014) stated that there are numerous nutritional benefits from tra fish skin such as Acid-solubilized collagen (ASC) extracted by acetic acid and purified by dialysis, lyophilization, and super-critical (SC) CO2 extraction techniques. Some parameters involving yield of salt removal about $93.3 \%$ (in 24h) in stirring condition at $24 \mathrm{~h}$, and lipid extraction process is at $91.6 \%$ at conditions: Pressure- 200 bar, CO2 flow rate of $10 \mathrm{~g} / \mathrm{min}$, the temperature of $38^{\circ} \mathrm{C}$, etc. They found no smell, no color, high molecular weight in the obtained collagen with lipid $(0.33 \%)$, ashes $(0.29 \%)$ that proper for cosmetic, pharmaceutical, and food application (Soloviy et al., 2020). Nhu et al. (2015) specified that they pay attention to rising environmental sustainability conditions of favorable aquaculture-based products for Pangasius fillets.

Besides, Thi et al. (2016) reported that from exporting data, overseas markets such as European countries, the U.S., Canada, Japan, etc., highly valued Vietnamese catfish (Pangasius hypophthalmus). So, they studied the microbiota of frozen Vietnamese catfish products with samples of Pangasius steaks from supermarkets (in Ghent, Belgium), portions, and fillets from six brands.

As well, Guimarães et al. (2015) pointed throughout the evaluation process to ensure good quality of tra fish on the production value chain for consumers worldwide because there is evidence during testing specimens in Vietnam for parameters of chemical quality related to frozen Pangasius hypophthalmus. For instance, the experiment decides proximate composition (Sărăţeanu \& Moisuc, 2011), pH, ammonia, biogenic amines (BAs), total mercury ( $\mathrm{Hg})$, malondialdehyde (MDA), and polyphosphate and figure out moisture, protein, lipid, and ash values were between $83.83-85.59,12.51-14.52,1.09-1.65$, and $0.76-2.38 \mathrm{~g} 100 \mathrm{~g}-1$, accordingly. Next, scientists find out that in $30 \%$ of the samples, they detect fraud by excessive polyphosphate addition, and in $50 \%$ of the samples, $\mathrm{Hg}$ was detected above the recommended limit. Researchers also see that low concentrations of individual $\mathrm{BAs}$ and $\mathrm{pH}$ values were found in this study and ranged from 5.88 to 6.18 for compounds from the degradation process (Ateş \& Argun, 2021; Bartkiene et al., 2019; Guimaraes, 2016). Then they find out ammonia concentration indicated that a degradation process initiated in $80 \%$ of the samples, and $20 \%$ of the samples were in an advanced deterioration process. Besides, failures to some extent during transportation and/or storage were found as MDA values (1.21-7.88 $\mathrm{mg} \mathrm{kg}-1$ ), so they stated that quality control measures must be conducted on the Pangasius producing process.

Seshagiri et al. (2013) stated that, in Vietnam agriculture, in terms of processing, in the past, pangasius was exported mainly in the form of frozen fillets, but up to now, most businesses have invested in processing technology lines with diverse products, in addition to other types of products. Fillet also has products such as fish cakes, breaded, pangasius cut with lemongrass salt, cut into pieces, sandwiches, sesame cakes, baby corn bags, tomatoes stuffed with pangasius, squash stuffed with pangasius, stomach stuffed with rolls seafood, sausages, fillet rolls stuffed with shrimp, pangasius stuffed with salmon. Besides, some businesses also have dried processed pangasius products such as dried tra fish bubble, dried pangasius (Kumar et al., 2017; Lima et al., 2014; Neiva et al., 2011). In Lu et al. (2018), current cluster studies primarily discussed cluster phenomena from either a microlevel or mesolevel. So, it's argued that studying relations among clusters would increase understanding of clusters, and such a research topic is worth becoming a new research orientation for cluster theory (Rezaei \& Vadiati, 2020). 


\section{Seafood processing - a case study of fish pangasius in Mekong delta in Vietnam}

The present study mainly uses qualitative analysis, synthesis, and inductive methods and dialectical materialism methods. Besides, this study also uses statistics and analysis in order to make a policy recommendation.

\subsection{First, we describe the process of making fillet pangasius (tra fish) in Vietnam as follows:}

\section{Step 1: pharyngectomy (removal of secretions)}

Fish, after being received, move to the pharynx cutting stage through the feed chute. Then the pharyngeal cutter will use a specialized knife to cut into the pharynx of the fish, and the purpose is to kill the fish, remove all the blood in the fish's body and make the fish meat after the fillet white with high sensory value.

The fish is put on a table with running water, and the worker holds the fish with his left hand; the fish head is facing the knife handle, the fish belly is facing the worker. The hand that uses the knife stabs directly into the throat where the pharynx and gills meet, then presses the knife firmly down to cut the fish's pharynx, causing the throat to cut, and the blood will escape. Then the workers put the fish in the slant, the fish run down the sink, the fish time in the tub is $5-10$ minutes, then the fish is poured onto the fillet table.

\section{Step 2: wash}

Put water into the 1000 liter washing machine sink, put in the flake ice, set the temperature to $20-25^{\circ} \mathrm{C}$, and press the start button.

After cutting the pharynx, the fish is transferred to washing stage 1 to wash off the blood, slime, and impurities on the surface of the fish. The fish is washed with an automatic washing machine. Soak fish for 7-10 minutes.

Note: $\mathrm{T}^{\circ}$ water $20-25^{\circ} \mathrm{C}$ for the purpose of easy blood draining out, muscles are not stiff and easy to fillet. $\mathrm{T}^{\circ}$ is higher than fish that are easy to peel, denature, grow quickly..., lower $\mathrm{T}^{\circ}$, hard muscle is difficult to fillet

\section{Step 3: fillet}

Conveyor will transport fish after washing machine one to fillet stage. Fillet stage with the purpose of separating the fish meat from the head, fish bones, and viscera. The operation must be accurate and in accordance with the technical requirements. The piece of fish after the fillet must be flat and beautiful. No organ ruptures. Do not tear the flesh. Thoroughly remove the head meat. No bones left.

Workers open the faucet and put the fish on the cutting board, the dominant hand holds the knife, the opposite hand holds the fish head towards the knife handle, the fish belly faces the fillet, the dominant hand holds the knife and cuts a line behind the fish barbs, press firmly the tip of the knife to the spine and then round the knife to cut close to the spine axis, to the dorsal spine, gently slide the tip of the knife up to cut close to the spine axis extending to the tail. The tip of the knife must be sliced close to the spine to remove all the meat; the tip of the knife should not penetrate more than $1 / 2$ the width of the fish. Tilt the knife back, hold the piece of fish slightly raised, cut back close to the spine from the tail to the head, then put the tip of the knife into the abdomen; the tip of the knife points forward and then pulls it down, then the fiddle hand holds the piece of fish, the other hand plays. Cut off the sticky part of the fish's belly, then put the fish in the basket on the table.

Turn the fish over, head to the opposite hand, back to the fillet, and follow the same action as at the beginning; we get the 2 nd piece of fish. The rest of the bones, heads, and internal organs must be put in the by-product basket below and taken out through the by-product door.

\subsection{Second, we can see processes to make delicious tra fish (pangasius) food at restaurants}

For instance, Figure 2 shows tra fish (pangasius) processed in the kitchen and displayed at restaurants.

Next, we can make tra fish (pangasius) with soup; seeing the below picture, we see the delicious seafood from tra fish (or pangasius) in the Mekong delta.

\section{Analysis of development of the pangasius industry groups in the Mekong Delta}

Looking at Table 1, we see the production quantity of fish pangasius in the Mekong delta:

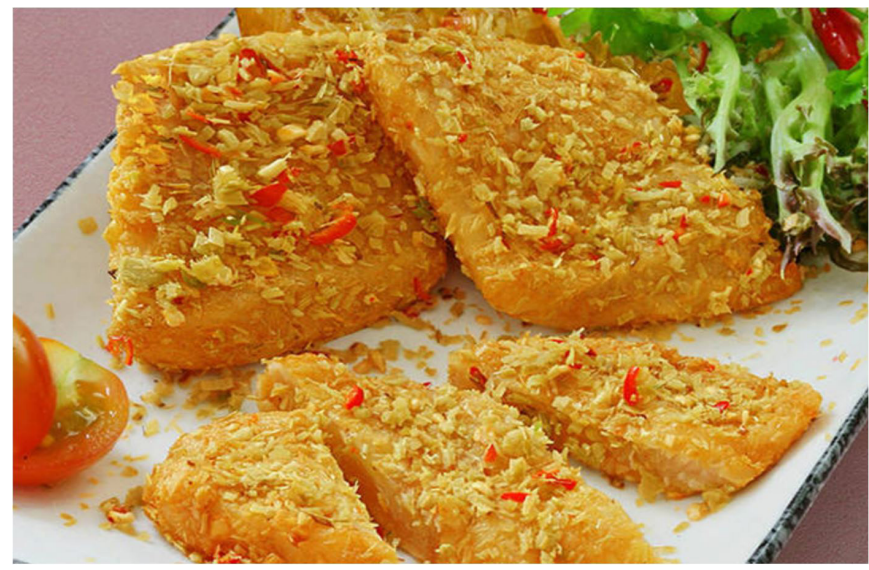

Figure 2. Tra fish (pangasius) processed with chili.

Table 1. Quantity of fish pangasius in Mekong Delta 2015-2019.

\begin{tabular}{ccc}
\hline \multicolumn{3}{c}{ Area and quantity of pangasius } \\
\hline Year & Area (ha) & Quantity (million tons) \\
\hline 2015 & 5.623 & 1,11 \\
2016 & 5.893 & 1,19 \\
2017 & 6.078 & 1,25 \\
2018 & 6.418 & 1,42 \\
2019 & 6.675 & 1,58 \\
\hline
\end{tabular}

Source: General Bureau of Fisheries \& Ministry of Agriculture. 
In 2019, while the pangasius farming area increased by $4 \%$, production increased by $22 \%$, showing that pangasius farmers have better investments in seed and technology to increase productivity.

Dong Thap, An Giang, Ben Tre, Can Tho, and Vinh Long are five provinces in the Mekong Delta River which have the biggest areas of feeding/investing in fish pangasius (Table 1). The supporting role of the Department of Agriculture and Rural Development, the Department of Industry and Trade, the Department of Science and Technology of the provinces in the Mekong Delta in the proposal of planning, research and technology transfer, technology for breeding pangasius, processing industry, attracting investment, promoting trade, exporting markets, providing information on technical barriers to trade (TBT), supporting linkages and cooperation in developing the pangasius industry cluster and enhance added value in the value chain of the pangasius industry in the Mekong Delta.

Processed pangasius products, including Frozen Pangasius, Frozen Fillet, Breaded Pangasius, Dried Pangasius Pangasius, Fish Skin, Bubbles, Stomach, Processed Pangasius Fat, etc. In which: Main products: frozen pangasius fillets, frozen pangasius, etc. by-products: value-added processed products, fish skin, bubbles, stomachs, fat of processed pangasius, estimated processing rate/farming output (\%): 95\%. Besides, the highest consumed quantity and highest export volume took place in the year 2018, till 2019-2020 declines as impacts from Covid 19 (Table 2).

Pangasius in the Mekong Delta has been exported to 133 countries and territories, such as China, the US, the EU, Mexico, Brazil, Australia, Japan, Canada, etc.

Seshagiri et al. (2013) said linking along the pangasius value chain between pangasius enterprises, cooperatives, households, and pangasius processing, consumption, and export enterprises. The linkage of production stages, from pangasius farming, collection to processing and consumption and export of pangasius products, was previously usually undertaken by different entities, such as pangasius farming is mainly households and some cooperatives/enterprises; collectors are usually traders and some enterprises that process and consume, and processing is undertaken by enterprises investing in processing technology. However, at present, many companies invest in a closed loop between the stages from pangasius farming to processing, consumption, and export.

\section{Solutions for pangasius industry groups development in Mekong Delta}

The focus on implementation is to improve the quality of the seed, the quality of raw pangasius at the rearing stage associated with the improvement of environmental quality.

Table 2. Pangasius consumption in the Mekong Delta in 2017-2019.

\begin{tabular}{cccl}
\hline Year & $\begin{array}{c}\text { Consumed } \\
\text { quantity (tons) }\end{array}$ & $\begin{array}{c}\text { In which: Export } \\
\text { (ton) }\end{array}$ & \multicolumn{1}{c}{ Note } \\
\hline 2017 & 1.122 .000 & 720.000 & Pangasius products \\
2018 & 1.309 .000 & 780.000 & for export \\
2019 & 1.263 .000 & 740.000 & $\begin{array}{l}\text { are processed } \\
\text { pangasius products }\end{array}$ \\
\hline
\end{tabular}

In particular, increasing the application of new technologies in the rearing stage of fish such as: using probiotics, vaccines, and rearing in cool houses to increase the resistance of fingerlings to improve survival rate and efficiency for production. To encourage businesses with potential and resources to participate in selecting and breeding pangasius broodstock with quality according to production requirements.

In addition, it is strictly implementing the provisions of Decree 26/2019/ND-CP dated March 8, 2019, detailing a number of articles and measures to implement the Law on Fisheries in the management of aquaculture, processing, pangasius export. Actively control product quality, gradually bringing standards such as BAP, Global GAP into seed production facilities. At the same time, organize training and improve production skills for management and labor force in farming areas to apply technological advances to reduce production costs and ensure seed quality, food safety, and hygiene.

In addition, in terms of market promotion and development, the Vietnam Pangasius Association said that it is necessary to focus on developing the available markets in the US, EU, China, and ASEAN.

In fact, looking at the below chart (Figure 3), we see the top 5 export markets of Vietnam: China-Hongkong, US, ASEAN, EU, and Mexico.

Brunton et al. (2019) stated that for fillets Pangasius, the downstream cold chain would be simulated conditions of temperature for its quality change. Then storage time was performed with chemical, sensory and microbiological analyses. There are five stable quality indexes -QI $(1,4,9,15$, and $19 \pm$ $1{ }^{\circ} \mathrm{C}$ ) and three levels of temperatures, processed more quickly at higher temperatures. Storage conditions will involve remaining total volatile basic nitrogen with an acceptable limit.

Regarding development policies, Seshagiri et al. (2013) mentioned the linkage between enterprises and other related organizations: Pangasius enterprises and related organizations have links and support each other according to the following links (see Figure 4: Linking by value chain).

On the other hand, the development of the pangasius industry and the pangasius industry cluster has the following limitations:

Regarding production linkage: The association between enterprises and enterprises, cooperatives, people, as well as with

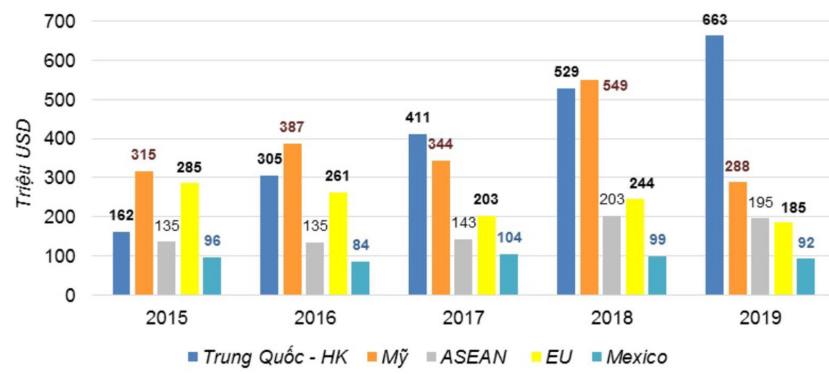

Figure 3. Top 5 export markets of Vietnam 2015-2019. 


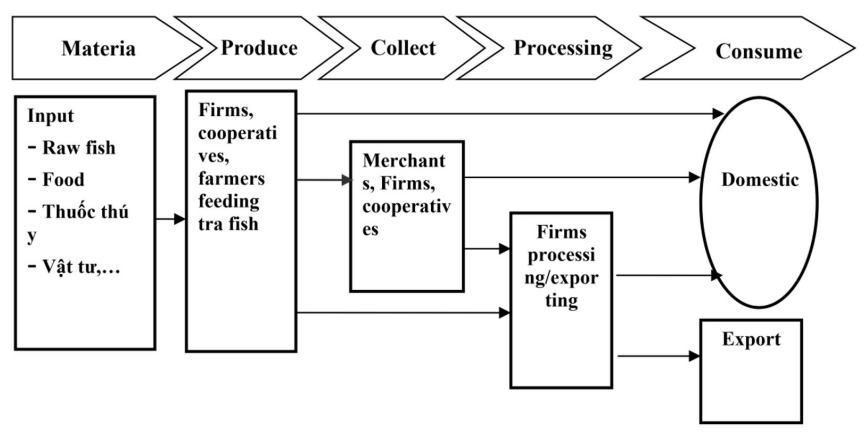

Figure 4. Pangasius (Tra fish) fish value chain diagram.

scientific and technological organizations (universities, research institutes) and other relevant organizations. Related to farming in farming, processing, consuming, building, and developing product brands, although some results have been achieved, but not really linked and harmonized in terms of interests in the product value chain. And the efficiency is still low and unsustainable. Regarding farming techniques and processing technology: The pangasius industry is still facing difficulties in seed quality, has not been proactive in food production, processing industry, and product diversification. High value-added products are limited. The empirical results have shown that the process of making fillet tra fish (pangasius) needs to have enough experience, skills and take place under certain conditions.

\section{Conclusions}

Promote linkages between the State, enterprises, institutes/ schools, and farmers: The State supports enterprises and farmers of pangasius by planning farming areas, processing industry clusters, and promoting policies. Fishery, industrial promotion, trade promotion and development and implementation of scientific and technological programs, projects and projects on breeds, farming techniques, disease control, processing, etc., in order to improve productivity, output, quality, and efficiency of the pangasius industry. Encourage enterprises to support and cooperate with farmers (pangasius farmers) to build material areas for the processing industry and export pangasius of enterprises, such as signing product sales contracts and supporting investing in raising pangasius (seeds feed, aquatic medicine, etc.). Banks create favorable conditions for farmers to borrow capital to raise pangasius with preferential interest rates. Encourage cooperation and support of scientists in research activities, technology transfer, and training for businesses and farmers on pangasius farming and processing techniques.

Linking between the state, businesses, scientists, and farmers in the development of the pangasius industry is essentially a form of market linkage and benefits through policies that help harmonize the parties' interests.

\section{References}

Ateş, H., \& Argun, M. E. (2021). Advanced oxidation of landfill leachate: removal of micropollutants and identification of by-products. Journal of Hazardous Materials, 413, 125326. PMid:33611035.
Baldassarre, B., Schepers, M., Bocken, N., Cuppen, E., Korevaar, G., \& Calabretta, G. (2019). Industrial Symbiosis: towards a design process for eco-industrial clusters by integrating Circular Economy and Industrial Ecology perspectives. Journal of Cleaner Production, 216, 446-460.

Bartkiene, E., Mozuriene, E., Lele, V., Zokaityte, E., Gruzauskas, R., Jakobsone, I., Juodeikiene, G., Ruibys, R., \& Bartkevics, V. (2019). Changes of bioactive compounds in barley industry by-products during submerged and solid state fermentation with antimicrobial Pediococcus acidilactici strain LUHS29. Food Science \& Nutrition, 8(1), 340-350. PMid:31993160.

Bekele, G. W., \& Jackson, R. (2006). Theoretical perspectives on industry clusters. Regional Research Institute Working Papers, 92, 2006-5.

Brunton, L. A., Desbois, A. P., Garza, M., Wieland, B., Mohan, C. V., Häsler, B., Tam, C. C., Le, P. N. T., Phuong, N. T., Van, P. T., NguyenViet, H., Eltholth, M. M., Pham, D. K., Duc, P. P., Linh, N. T., Rich, K. M., Mateus, A. L. P., Hoque, M. A., Ahad, A., Khan, M. N. A., Adams, A., \& Guitian, J. (2019). Identifying hotspots for antibiotic resistance emergence and selection, and elucidating pathways to human exposure: Application of a systems-thinking approach to aquaculture systems. The Science of the Total Environment, 687, 1344-1356. PMid:31412468.

Chakrabarty, S. (2020). Value creation in industrial clusters: The strategic nature of relationships with stakeholders and the policy environment. Journal of Strategy and Management. 13(4), 535-550.

Choi, S. C., \& Jiang, X. (2021). Decline of local industrial clusters in japan and the role of merchant coordinators for sustainable development of these clusters. Kansai University Review of Business and Commerce, 20, 21-44.

Guimaraes, C. F. M. (2016). Qualidade química e efeito da radiação Uv-C em filés de peixe panga (Pangasius hypophthaimus) (Tese de doutorado). Universidade Federal Fluminense, Rio de Janeiro.

Guimarães, C. F. M., Mársico, E. T., Monteiro, M. L. G., Lemos, M., Mano, S. B., \& Conte, C. A. Jr. (2015). The chemical quality of frozen Vietnamese Pangasius hypophthalmus fillets. Food Science \& Nutrition, 4(3), 398-408. PMid:27247770.

Han, Y., Chen, G., \& Poh, E. (2018). Effects of informal contracts on innovative cooperation among enterprises in industrial clusters: An evolutionary game analysis. Discrete Dynamics in Nature and Society, 2018, 5267357.

Huy, D. T. N. (2016). Estimating beta of Viet Nam listed public utilities, natural gas and oil company groups during and after the financial crisis 2007-2011. Economic and Business Review, 15(1).

Kaewnuratchadasorn, P., Smithrithee, M., Sato, A., Wanchana, W., Tongdee, N., \& Sulit, V. T. (2020). Capturing the impacts of COVID-19 on the fisheries value chain of southeast asia. Fish for the People, 18(2), 2-8.

Kumar, G. P., Xavier, K. M., Nayak, B. B., Kumar, H. S., Venkateshwarlu, G., \& Balange, A. K. (2017). Effect of different drying methods on the quality characteristics of Pangasius hypophthalmus. International Journal of Current Microbiology and Applied Sciences, 6, 184-195.

Lee, H. L., \& Whang, S. (2004). E-business and supply chain integration. In T. P. Harrison, H. L. Lee, \& J. J. Neale (Eds.), The practice of supply chain management: where theory and application converge (pp. 123138). New York: Springer.

Lima, R. L., Enke, D. B. S., Braun, N., \& Fracalossi, D. M. (2014). Phosphorus reduction by sifting fish waste meal. Ciência Rural, 44(10), 1841-1844.

Lindsay, V. J. (2005). The development of international industry clusters: a complexity theory approach. Journal of International Entrepreneurship, 3(1), 71-97. 
Lu, R., Reve, T., Huang, J., Jian, Z., \& Chen, M. (2018). A literature review of cluster theory: are relations among clusters important? Journal of Economic Surveys, 32(4), 1201-1220.

Malmberg, A., Sölvell, Ö., \& Zander, I. (1996). Spatial clustering, local accumulation of knowledge and firm competitiveness. Geografiska Annaler. Series B, Human Geography, 78(2), 85-97.

Misganaw, G. (2020). Assessment of dairy value chain sustainability, constraints and opportunities in Aksum, Central Tigray, Ethiopia. Online Journal Animal Feed Research, 10(1), 41-52

Motoyama, Y. (2008). What was new about the cluster theory? What could it answer and what could it not answer? Economic Development Quarterly, 22(4), 353-363.

Neiva, C. R. P., Machado, T. M., Tomita, R. Y., Furlan, É. F., Lemos, M. J. No., \& Bastos, D. H. M. (2011). Fish crackers development from minced fish and starch: an innovative approach to a traditional product. Food Science and Technology, 31(4), 973-979.

Neubacher, H. (2010). Viet Nam: seafood from Waterland. Rome: FAO.

Nguyen, T. A. T., \& Jolly, C. M. (2018). Macro-economic and product challenges facing Vietnamese the Pangasius industry. Reviews in Fisheries Science \& Aquaculture, 26(2), 183-194.

Nhu, T. T., Schaubroeck, T., Meester, S., Duyvejonck, M., Sorgeloos, P., \& Dewulf, J. (2015). Resource consumption assessment of Pangasius fillet products from Vietnamese aquaculture to European retailers. Journal of Cleaner Production, 100, 170-178.

Pham, T. T. H., \& Nguyen, B. G. (2012). Industrial Clustering Policy and Economic Restructuring in Vietnam. MPRA Paper, (41471).
Rezaei, K., \& Vadiati, M. (2020). A comparative study of artificial intelligence models for predicting monthly river suspended sediment load. Journal of Water and Land Development, (45), 107-118.

Sărăţeanu, V., \& Moisuc, A. (2011). Influence of Prunus spinosa L. shrub on the grassland vegetation in western Romania. Journal of Water and Land Development, 15(1), 65-71.

Seshagiri, B., Mishra, S. S., Swain, S. K., Pillai, B. R., Satyavati, C., Sravanti, Y., Rangacharyulu, P. V., Rathod, R., \& Ratnaprakash, V. (2013). Sustainability of striped catfish (Pangasianodon hypophthalmus, Sauvage, 1878) culture in Andhra Pradesh, India. Methods, 9, 8.

Soloviy, C., Malovanyy, M., Nykyforov, V., \& Dihtyar, S. (2020). Critical analysis of biotechnologies on using resource potential of hydrobionts. Journal of Water and Land Development, (4), 143-150.

Thi, A. N. T., Samapundo, S., Devlieghere, F., \& Heyndrickx, M. (2016). Microbiota of frozen Vietnamese catfish (Pangasius hypophthalmus) marketed in Belgium. International Journal of Food Contamination, $3(1), 1-9$.

Tuan, P. D., \& Dzung, N. H. (2014). Extraction and isolation of collagen from the skins of Basa Fish (Pangasius Hypophthalmus). Vietnam Journal of Science and Technology, 52(4), 431.

Turkina, E., \& Van Assche, A. (2018). Global connectedness and local innovation in industrial clusters. Journal of International Business Studies, 49(6), 706-728.

Wu, Y. (2018). Development Patterns and Policy Suggestions for Cultural and Creative Industry Clusters. In X Xiao (Ed.), 2nd International Conference on Education Science and Economic Management (ICESEM 2018). Xiamen: Atlantis Press. 